\title{
Effect of Knowledge, Peer Group, Family, Cigarette Price, Stipend, Access to Cigarette, and Attitude, on Smoking Behavior
}

\author{
R. Asto Soesyasmoro'), Argyo Demartoto'), Rita Benya Adriani1) \\ ${ }^{1)}$ School of Health Polytechnics Surakarta \\ 2)Faculty of Social and Political Sciences, Universitas Sebelas Maret
}

\begin{abstract}
Background: Passive smokers inhale $75 \%$ of ambient smoke and $50 \%$ of exhaled smoke. A cigarette contains 4.000 poisonous chemical agents, at least 69 of which are carcinogenic. Therefore ambient tobacco smoke is detrimental to health. The purpose of this study was to analyze the effect of knowledge, peer group, family, cigarette price, stipend, access to cigarette, and attitude, on smoking behavior.

Subjects and Method: This was an analytic and observational study with cross sectional design. This study was conducted at School of Health Polytechnics, Surakarta, Central Java. A total of 105 male students was selected for this study. The dependent variable smoking status. The independent variables knowledge, peer group, family, cigarette price, stipend, access to cigarette, and attitude. The data were collected by a set of questionnaire, and were analyze by logistic regression model.

Results: High smoking peer group $(\mathrm{OR}=3.21 ; 95 \% \mathrm{CI}=1.18-8.72 ; \mathrm{p}=0.022)$, high stipend $(\mathrm{OR}=$ 3.66; 95\% $\mathrm{CI}=1.28-10.49 ; \mathrm{p}=0.016)$, convenient access to cigarette $(\mathrm{OR}=3.02 ; 95 \% \mathrm{CI}=1.04$ to 8.73; $\mathrm{p}=0.042)$ increased the likelihood of smoking. High knowledge about tobacco smoking $(\mathrm{OR}=0.35 ; 95 \% \mathrm{CI}=0.13-0.95 ; \mathrm{p}=0.039)$ and non-smoking family $(\mathrm{OR}=0.16 ; 95 \% \mathrm{CI}=0.03$ to $0.70 ; \mathrm{p}=0.015)$ decreased the likelihood of smoking. High price of cigarette $(\mathrm{OR}=0.86 ; 95 \% \mathrm{CI}=$ 0.23 to $3.19 ; \mathrm{p}=0.819)$ and possitive attitude $(\mathrm{OR}=0.88 ; 95 \% \mathrm{CI}=0.33$ to $2.36 ; \mathrm{p}=0.795)$ did not show statistically significant effect on smoking.

Conclusion: Smoking peer group, stipend, access to cigarette increase the probability of smoking. Knowledge about tobacco smoking and non-smoking family decrease the probability of smoking.
\end{abstract}

Keywords: knowledge, peer group, family, cigarette price, stipend, access to cigarette, attitude, smoking behavior

Correspondence:

R. Asto Soesyasmoro. School of Health Polytechnics, Surakarta. Email: asto_monti@yahoo.co.id.

\section{BACKGROUND}

The widespread impacts of using tobacco products on public health in the world have rised great concern from the international community. The World Health Organization (WHO) arranges an instrument to do tobacco control effectively, precisely and comprehensively. It is known as Framework Convention on Tobacco Control (FCTC). The same concern also emerges in public discourse in the country.

Groups of Civil Society Organization (CSO) in the Indonesian NGO Coalition for
Tobacco Control states that the Indonesian Goverment must do immediate and strategic actions on the situation named "National Emergency Threats of Tobacco Consumption in Indonesia" because the smokers in Indonesia have consumed cigarette by no less than 360 billion cigarettes per year (Mulyana, 2014).

Cigarettes that have been consumed produce cigarette smoke which is very dangerous for the smoker health as active smokers, as well as passive smokers. Basically, cigarette smoke consists of the main 
fumes which contain 25\% dangerous levels and side fumes which contain $75 \%$ dangerous levels. Passive smokers inhale $75 \%$ of hazardous ingredients and half of the smoke exhaled. A cigarette contains 4000 toxic chemicals and no less than 69 of them are carcinogenic. Therefore, cigarettes and environment which contaminate with cigarette smoke could endanger health. These chemical contents cause various noncommunicable diseases such as heart disease and vascular disorders, strokes, lung cancer, and oral cancer. In addition, cigarettes cause fertility decline, slow fetal growth both physically and IQ, infant immunity disorders, and increase number of mortality (Aditama, 2006).

There are around $34.7 \%$ of Indonesia's population aged 10 years and over are smokers. Nationally, the prevalence of smokers in 2010 was $34.7 \%$; the highest number was in Central Kalimantan Province (43.2\%) and the lowest number was in Southeast Sulawesi (28.3\%). The prevalence of smokers aged 10-14 in 1995 was $0.3 \%$ or around 71.000 people. In addition, in 2010, it increased sharply by 426.000 people. In other words, in 15 years, the number of smokers in this age group increase sixfold. There are more than 40.3 million children living with smokers and exposed to cigarette smoke; They are at risk of experiencing bronchitis, pneumonia, middle ear infections, asthma, and lung growth delays; it also caused poor health in adulthood ( $\mathrm{MOH}, 2010)$.

The current smoking behavior can cause death to 500 million people with more than half of them were children and adolescents; it occurs due to the high number of tobacco consumption. Beginner smokers in Indonesia are getting younger. Various studies have shown that adolescents aged 11-18 years have smoked already. The risk of smoking will lead to negative effects on health, especially for adolescents who have a potential to become prospective family-builders and the next generation nation. In addition, the data of WHO state that 30\% smokers in the world are adolescents (Mubarok, 2009).

Adolescents are more commonly known as stage of adolescence which has a broad meaning. In this case, maturity in mental, emotional, spatial, and physical greatly affect the development. In this stage of adolescence, they spread their wings with various dreams. Basically, they have great curiosity, so they tend to be easily influenced by daily habits and the influence of the environment around them. Environmental factors have a very important role for adolescents development. Generally, the adolescents choose to socialize based on the characteristics of adolescent friendship. The characteristics of adolescent friendship are influenced by the similarity of age, gender, and race. The similarity in consuming drugs, cigarettes and liquor greatly affect in selecting friends (Permatasari and Wahyuni, 2011).

The problem formulation in this study is: "Is there any effect of knowledge about smoking, peer group, family, cigarette price, stipend, access to cigarettes, and attitudes about the dangers of smoking on smoking behavior in students at School of Health Polytechnics, Surakarta?"

This study aimed to know the effect of knowledge, peer group, family, cigarette price, stipend, access to cigarette, and attitude about the dangers of smoking, on smoking behavior in students at School of Health Polytechnics, Surakarta.

\section{SUBJECTS AND METHOD}

This study was an analytic and observational study with cross sectional design. The population of this study was 105 male students at School of Health Polytechnics, 
Surakarta. This study used simple random sampling technique. The independent variables were knowledge, peer group, family, cigarette price, stipend, access to cigarette, and attitude. The dependent variable was smoking status. This study used logistic regression model to analyze the data.

\section{RESULTS \\ 1. Univariate Analysis}

The result of the characteristic of subject of the study in table 1 shows that most of students had good knowledge about smoking (50.5\%), thstae peer group influence was high (63.8\%), the family influence was high (79.0\%), the cigarette price was cheap (84.8\%), most of the students had the support of stipend to buy cigarette (69.5\%), the access to get cigarette was easy $(69.5 \%)$, and most of students had positive attitude about the dangers of smoking (52.4\%).

Table 1. The characteristic of sample

\begin{tabular}{lcc}
\hline Knowledge & n & \% \\
\hline Poor & 52 & 49.5 \\
Good & 53 & 50.5 \\
Peer Group Influence & & \\
Low & 38 & 36.2 \\
High & 67 & 63.8 \\
Family Influence & & \\
Low & 22 & 21.0 \\
High & 83 & 79.0 \\
Cigarette Price & & \\
Expensive & 16 & 15.2 \\
Cheap & 89 & 84.8 \\
Stipend & & \\
Without support & 32 & 30.5 \\
Support & 73 & 69.5 \\
Access to cigarette & & \\
Difficult & 32 & 30.5 \\
Easy & 73 & 69.5 \\
Attitude & & \\
Negatifve & 50 & 47.6 \\
Positive & 55 & 52.4 \\
\hline
\end{tabular}

Table 2 shows that there was an effect of knowledge about smoking on smoking behavior which statistically significant $(\mathrm{OR}=0.37 ; \mathrm{p}=0.018)$. Students with poor knowledge about smoking had 0.37 times greater possibility of smoking than students with good knowledge.

\section{Bivariate Analysis}

Table 2. The chi square test of knowledge on smoking behavior

\begin{tabular}{lcccc}
\hline \multirow{2}{*}{$\begin{array}{c}\text { Knowl } \\
\text { edge }\end{array}$} & \multicolumn{2}{c}{$\begin{array}{c}\text { Smoking } \\
\text { Behavior }\end{array}$} & \multirow{2}{*}{ OR } & p \\
\cline { 2 - 3 } & No & Yes & & \\
\hline Low & 13 & 39 & 0.37 & 0.018 \\
High & 25 & 28 & & \\
Total & 38 & 67 & & \\
\hline
\end{tabular}

Table 3 shows that there was an effect of peer group on smoking behavior which was statistically significant $(\mathrm{OR}=4.38 ; \mathrm{p}<$ 0.001).

Table 3. The Chi Square Test of Peer Group on Behavior

\begin{tabular}{ccccc}
\hline \multirow{2}{*}{$\begin{array}{c}\text { Peer } \\
\text { Group }\end{array}$} & \multicolumn{2}{c}{$\begin{array}{c}\text { Smoking } \\
\text { Behavior }\end{array}$} & \multirow{2}{*}{ OR } & p \\
\cline { 2 - 3 } & No & Yes & & \\
\hline Low & 22 & 16 & 4.38 & 0.001 \\
High & 16 & 51 & & \\
Total & 38 & 67 & & \\
\hline
\end{tabular}

Table 4 shows that there was an effect of family on smoking behavior which statistically significant $(O R=0.22 ; p=p=0.013)$. It showed that the effect of smoking family had 0.22 times greater possibility to make students smoke.

Table 4. The Chi Square Test of Family on Smoking Behavior

\begin{tabular}{lcccc}
\hline \multirow{2}{*}{$\begin{array}{c}\text { Family } \\
\text { influence }\end{array}$} & \multicolumn{2}{c}{$\begin{array}{l}\text { Smoking } \\
\text { Behavior }\end{array}$} & \multirow{2}{*}{ OR } & p \\
\cline { 2 - 3 } & No & Yes & & \\
\hline Low & 3 & 19 & 0.22 & 0.013 \\
High & 35 & 48 & & \\
Total & 38 & 67 & & \\
\hline
\end{tabular}

Table 5 shows that there was no effect of cigarette price on smoking behavior $(\mathrm{OR}=1.46 ; \mathrm{p}=0.494)$. The cheap cigarettes 
had 1.46 times greater possibility to make students smoke compared to the expensive cigarretes.

Table 5. The chi square test of cigarette price on smoking behavior

\begin{tabular}{ccccc}
\hline \multirow{2}{*}{$\begin{array}{c}\text { Cigarette } \\
\text { Price }\end{array}$} & \multicolumn{2}{c}{$\begin{array}{c}\text { Smoking } \\
\text { Behavior }\end{array}$} & \multirow{2}{*}{ OR } & p \\
\cline { 2 - 3 } & No & Yes & & \\
\hline Low & 7 & 9 & 1.46 & 0.494 \\
High & 31 & 58 & & \\
Total & 38 & 67 & & \\
\hline
\end{tabular}

Table 6. The Chi Square Test of Stipend on Smoking Behaviour

\begin{tabular}{lllll}
\hline \multirow{2}{*}{ Stipend } & \multicolumn{2}{l}{$\begin{array}{l}\text { Smoking } \\
\text { Behavior }\end{array}$} & OR & p \\
\cline { 2 - 3 } & No & Yes & & \\
\hline Without & & & & \\
Support & 18 & 14 & & \\
Support & 20 & 53 & 3.41 & 0.005 \\
Total & 38 & 67 & & \\
\hline
\end{tabular}

Table 6 shows that there was an effect of stipend on smoking behavior which statistically significant $(\mathrm{OR}=3.41 ; \mathrm{p}=0.005)$. The supportive stipend had 3.41 times greater possibility to make students smoke.

\section{Multivariate Analysis}

Table 9. The multiple logistic regressions

\begin{tabular}{lcccc}
\hline \multirow{2}{*}{ Independent Variables } & \multirow{2}{*}{ OR } & \multicolumn{2}{c}{ 95\% CI } & \multirow{2}{*}{ p } \\
\cline { 3 - 4 } & & Lower limit & Upper limit & 0.039 \\
Knowledge (high) & 0.35 & 0.13 & 0.95 & 0.022 \\
Peer influence (high) & 3.21 & 1.18 & 8.72 & 0.015 \\
Family influence (high) & 0.16 & 0.03 & 0.70 & 0.819 \\
Cigarette price & 0.86 & 0.23 & 3.19 & 0.016 \\
Stipend (support) & 3.66 & 1.28 & 8.46 & 0.042 \\
Access to cigarette (easy) & 3.02 & 1.04 & 2.36 & 0.795 \\
Attitude & 0.88 & 0.33 & & \\
-2 log likelihood = 102.4 & & & & \\
Nagelkerke $\mathrm{R}^{2}=38.9 \%$ & & & & \\
\hline
\end{tabular}

The Odd Ratio value of knowledge variable about cigarettes was 0.35 . Students
Table 7. The chi square test of access to cigarette on smoking behavior

\begin{tabular}{|c|c|c|c|c|}
\hline \multirow{2}{*}{$\begin{array}{l}\text { Access to } \\
\text { Cigarette }\end{array}$} & \multicolumn{2}{|c|}{$\begin{array}{l}\text { Smoking } \\
\text { Behavior }\end{array}$} & \multirow[t]{2}{*}{ OR } & \multirow[t]{2}{*}{ p } \\
\hline & No & Yes & & \\
\hline Difficult & 19 & 16 & 3.19 & 0.006 \\
\hline Easy & 19 & 51 & & \\
\hline Total & 38 & 67 & & \\
\hline
\end{tabular}

Table 7 shows that there was an effect of access to cigarette on smoking behavior $(\mathrm{OR}=3.19 ; \mathrm{p}=0.006)$. The easy access to cigarettes had 3.19 times greater possibility to make students smoke compared to the difficult access to cigarretes.

Table 8. The chi square test of attitude about the dangers of smoking on smoking behavior

\begin{tabular}{lcccc}
\hline \multirow{2}{*}{ Attitude } & \multicolumn{2}{c}{$\begin{array}{l}\text { Smoking } \\
\text { Behavior }\end{array}$} & \multirow{2}{*}{ OR } & p \\
\cline { 2 - 3 } & No & Yes & & \\
\hline Negative & 16 & 34 & 0.71 & 0.39 \\
Positive & 22 & 33 & & 4 \\
Total & 38 & 67 & & \\
\hline
\end{tabular}

Table 8 shows that there was no effect of the attitude about the dangers of smoking on smoking behavior $(\mathrm{OR}=0.71$; $\mathrm{p}=0.394)$. with poor knowledge about smoking had o.35 times greater possibility of smoking 
Journal of Health Promotion and Behavior (2016), 1(3): 202-211

https://doi.org/10.26911/thejhpb.2016.01.03.07

than students with good knowledge about smoking. The result of wald test showed that there was an effect of knowledge about smoking on smoking behavior in students which statistically significant $(\mathrm{OR}=0.35$; $95 \% \mathrm{CI}=0.13-0.95 ; \mathrm{p}=0.039$ )

The Odd Ratio value of the effect of peer group variable was 3.21. The high influence of peer group had 3.21 times greater possibility to make students smoke than the low influence of peer group. The result of wald test showed that there was an effect of peer group on smoking behavior in students which statistically significant $(\mathrm{OR}=3.21 ; 95 \% \mathrm{CI}=1.18-8.72 ; \mathrm{p}=0.022)$.

The Odd Ratio value of the effect of family variable was 0.16 . The effect of smoking family had 0.16 times greater possibility to make students smoke than the non-smoking family. The result of wald test showed that there was an effect of family on smoking behavior in students which statistically significant $(\mathrm{OR}=0.16 ; 95 \% \mathrm{CI}=$ 0.03-0.70; $\mathrm{p}=0.015$ ).

The Odd Ratio value of cigarette price variable was 0.86 . The cheap cigarettes had 0.86 times greater possibility to make students smoke than the expensive cigarettes. The result of wald test showed that there was an effect of cigarette price on smoking behavior in students, but statistically insignificant $\left(\mathrm{OR}=0.86 ; 95 \% \mathrm{CI}=0.23^{-}\right.$ 3.19; $\mathrm{p}=0.819$ ).

The Odd Ratio value of the effect of stipend variable was 3.66. The supportive stipend had 3.66 times greater possibility to make students smoke than the unsupportive stipend. The result of wald test showed that there was an effect of stipend on smoking behavior in students which statistically significant $(\mathrm{OR}=3.66 ; 95 \% \mathrm{CI}=$ 1.28-10.49; $\mathrm{p}=0.016$ ).

The Odd Ratio value of the effect of access to cigarette variable was 3.02. The easy access to cigarette had 3.02 times greater possibility to make students smoke than the difficult access to cigarette. The result of wald test showed that there was an effect of access to cigarette on smoking behavior in students which statistically significant $(\mathrm{OR}=3.02$; CI 95\%= 1.04-8.73; $\mathrm{p}=0.042$ ).

The Odd Ratio value of the effect of attitude about the dangers of smoking variable was 0.88 . The negative attitude about the dangers of smoking had 0.88 times greater possibility to make students smoke than the positive attitude about the dangers of smoking. The result of wald test showed that there was an effect of attitude about the dangers of smoking on smoking behavior in students, but statistically insignificant $\left(\mathrm{OR}=0.88\right.$; CI $95 \%=0.33^{-}$ 2.36; $\mathrm{p}=0.795)$.

The Nagelkerke $\mathrm{R}^{2}$ value was $38.9 \%$. The variables of knowledge about cigarettes, peers group, family, cigarette price, stipend, access to cigarettes, and attitude about the dangers of smoking could explain smoking behavior by $38.9 \%$ and $61.1 \%$ were explained by other factors outside of the study model.

\begin{tabular}{l}
\hline DISCUSSION \\
\hline The effect of knowledge about \\
smoking on smoking behavior \\
The result of this study showed that there \\
was an effect of knowledge about smoking \\
on smoking behavior. The result of wald \\
test showed that there was an effect of \\
knowledge about smoking on smoking \\
behavior in students which statistically sig- \\
nificant (OR= 0.35; 95\% CI= o.13 to o.95; \\
p= o.o39). This is in line with the beha- \\
vioral theory of Green et al, (1980) which \\
stated that behavior can be associated with \\
predisposing factors such as knowledge. \\
According to Azjen and Fishbein (2005) in \\
the behavior theory of Planned of Behavior \\
also stated that knowledge affects indivi-
\end{tabular}


dual behavior towards something such as smoking behavior in students.

The result of this study supported a study conducted by Maseda et al (2013) which showed that there is a correlation between knowledge about the dangers of smoking and smoking behavior in adolescent boys. Adolescents generally have high curiosity, because they are pushed by high curiosity.

Adolescent tend to want to explore and try everything they have never experienced. It is also pushed by desire as adults. As a result, they wanted to try to do what adults often do. As a result, the adolescent boys try to smoke clandestinely because they often see adults doing it (Ali and Asrori, 2010).

\section{The effect of peer group on smoking behavior}

The result of this study showed that there was an effect of peer group on smoking behavior. The result of wald test showed that there was an effect of peer group on smoking behavior in students which statistically significant $(\mathrm{OR}=3.21 ; 95 \% \mathrm{CI}=1.18$ 8.72; $\mathrm{p}=0.022)$.

This is in line with the behavioral theory of Green et al, (1980) which stated that the behavior of one of the factors that affects behavior was an reinforcing factor. This factor is obtained from the closest people and from the existence of social support such as friends. The result of this study supported the study conducted by Maseda et al (2013) which showed that the influence of peer group is the main reason on smoking behavior in students.

According to Hasanah and Sulastri (2011), there is a significant correlation between peer group and smoking behavior in male students. However, this result is not in line with study conducted by Azizah et al., (2013) which stated that there was no effect of peer group on smoking behavior.
Peer group who smoke will be able to affect other students to smoke, and vice versa. If students associate with other students who do not smoke, it also affects students not to smoke. This is in accordance with the study conducted by Komasari and Helmi (2000) which stated that the peer group environment provides an effective contribution by $33,048 \%$. The peer group environment has a very important meaning for adolescents. The need to be accepted and the effort to avoid rejection of peer groups are very essential requirements. Adolescent do not want to be rejected. They also avoid the term of 'sissy' or 'cowardice'. Smoking for adolescents is also a symbol: a symbol of power, masculinity, and maturity.

\section{The effect of family on smoking behavior}

The result of this study showed that there was an effect of family on smoking behavior in students which statistically significant $(\mathrm{OR}=0.16$; CI 95\%=0.03-0.70; $\mathrm{p}=0.015)$. This is in line with the behavioral theory of Green et al, (1980) which stated that the behavior of one of the factors that affect behavior was an reinforcing factor. This factor is obtained from the closest people and from the existence of social support given such as family.

The result of this study supported a study conducted by Geckova et al (2005) which showed that there are direct and indirect effects of smoking behavior in parents on smoking behavior in students. According to Hasnah and Sulastri (2010), there is an effect of parents support on smoking behavior in male students. Parents or family are the environmental factors related to smoking behavior.

Parental control is a characteristic that is considered to be significantly associated with some risk behaviors including smoking behavior (Hidayaningsih et al., 
2011). Family factors play a major role in the formation and appearance of behavior, both positive and negative.

The results of this study supported a study conducted by Theodorus (1994) which stated that the smoking family plays a significant role in the smoking behavior of their children compared to non-smoking family. According to the social cognitive learning theory, smoking is not only the learning process of children's observation of their parents or siblings, but also the positive reinforcements from their parents and the consequences of smoking which are pleasant by adolescent.

The effect of cigarette price on smoking behavior

The result of this study showed that there was an effect of cigarette price on smoking behavior in students, but statistically nonsignificant $(\mathrm{OR}=0.86 ; 95 \% \mathrm{CI}=0.23$ to 3.19; $\mathrm{p}=0.819$ ). Consumers' income will determine the amount of purchasing power they have. Therefore, for normal goods, the increase in consumer income will increase the demand of these goods. In the other hand, for inferior goods, the increase in consumer income will actually decrease demand for these goods. It shows that students basically do not have an ability to buy cigarettes, because they basically have not worked. Therefore, they do not get income and they rely on money given by their parents.

The more expensive cigarettes can not make students smoke. Meanwhile, cheap cigarettes can cause students smoke. According to income groups, the effect of increasing of cigarettes price for the poor was greater than those who were rich. An increase in cigarette price would decrease cigarette consumption by $10 \%$.

\section{The effect of stipend on smoking behavior}

The result of this study showed that there was an effect of stipend on smoking behavior in students which statistically significant $(\mathrm{OR}=3.66 ; 95 \% \mathrm{CI}=1.28$ to 10.49 ; $\mathrm{p}=0.016)$.

The result of this study supported a study conducted by Lindawati et al., (2011) showed that the enabling factor variable is stipend which significantly related to the smoking behavior in students. This is in accordance with Mc Donald's opinion (2011) which stated that low family income or poverty make adolescents feel anxious and depressed. The low family incomes (low stipend) are 5 times more difficult to stop consuming tobacco, compared to prosperous families (high stipend).

Oktavia (2010) also mentioned that there is a correlation between smoking behavior and stipend. The adolescents who has excess stipend had 20 times greater possibility of smoking than students who do not have excess stipend.

\section{The effect of accesss to cigarette on smoking behavior}

The result of this study showed that there was an effect of access to cigarette on smoking behavior in students which statistically significant $(\mathrm{OR}=3.02 ; 95 \% \mathrm{CI}=1.04$ to 8.73 ; $\mathrm{p}=0.042$ ).

This is in line with the behavioral theory of Green et al, (1980) which stated that the behavior of one of the factors that affected behavior is an reinforcing factor. This factor is obtained from the closest people and from the existence of social support such as access. Smoking habits occur because of the influence of social environments, peer group, parents, media, and so on. Smoking habits occured due to the influence of social environments, peer group, parents, media, and so on. There are more adolescents who smoke and addict to 
smoking every day due to the cigarette publications in a variety of print media and electronic which are getting more intense.

The enabling factor on smoking behavior was the availability of cigarettes sold around the house. In addition, the retail or bars cigarette sales increased children's and adolescents' access to cigarettes. The sales of bar cigarettes were commonly occured, even though it was sold at a low price. It made the easier access, especially for the sale of cigarettes. As a result, students obtained cigarettes easily.

The effect of attitude about the dangers of smoking on smoking behavior

The result of this study showed that there was an effect of attitude about the dangers of smoking on smoking behavior in students, but statistically significant (OR= 0.88; 95\% CI =0.33-2.36; $\mathrm{p}=0.795)$.

The result of this study supported a study conducted by Ariani (2011) which showed that there is no correlation between attitude and smoking behavior in students.

Based on the statement above, it is concluded that there was no correlation between attitudes towards health on smoking behavior. It may be caused by someone desire of smoking which was not only affected by attitudes towards health, but many factors influenced smoking behavior such as the belief in the consequences of smoking behavior. A person's decision to smoke or not was not entirely affected by the belief in the consequences of smoking behavior, but also by many factors. For example, an adolescent have a positive attitude towards smoking, but without being supported by beliefs about the negative consequences of smoking, the positive attitude towards health will not affect smoking behavior.

The limitation in this study is the sample of study which was only conducted in students at School of Health Polytechnics, Surakarta. The result of this study could not be generalized in other places or locations. In addition, the data in this study did not use in-depth interviews with students because it used a set of questionnaire.

This study concludes that there is an effect of knowledge about smoking on smoking behavior in students which statistically significant $(\mathrm{OR}=0.35 ; 95 \% \mathrm{CI}=$ 0.13 to $0.95 ; \mathrm{p}=0.039$ ).

There is an effect of peer group on smoking behavior in students which statistically significant $(\mathrm{OR}=3.21 ; 95 \% \mathrm{CI}=1.18$ - 8.72; $\mathrm{p}=0.022$ ).

There is an effect of family on smoking behavior in students which statistically significant $(\mathrm{OR}=0.16 ; 95 \% \mathrm{CI}=$ 0.03-0.70; $p=0.015$ ).

There is an effect of cigarette price on smoking behavior in students, but statistically insignificant $(\mathrm{OR}=0.86$; $95 \% \mathrm{CI}=$ o.23-3.19; $\mathrm{p}=0.819$ ).

There is an effect of stipend on smoking behavior in students which statistically significant $(\mathrm{OR}=3.66 ; 95 \% \mathrm{CI}=$ 1.28-10.49; $p=0.016)$.

There is an effect of access to cigarette on smoking behavior in students which statistically significant $(\mathrm{OR}=3.02 ; 95 \% \mathrm{CI}$ = 1.04-8.73; $\mathrm{p}=0.042$ ).

There is an effect of attitude about the dangers of smoking on smoking behavior in students, but statistically insignificant $(\mathrm{OR}=0.88 ; 95 \% \mathrm{CI}=0.33-2.36 ; \mathrm{p}=0.795)$.

The implication in this study shows that there is an effect of knowledge about smoking, peer group, family, stipend, and access to cigarettes on smoking behavior in students. It states that the planned behavior theory about behavior change is truly proven and can be used by health practitioners in providing health promotions about minimizing smoking behavior by 
Journal of Health Promotion and Behavior (2016), 1(3): 202-211

https://doi.org/10.26911/thejhpb.2016.01.03.07

combining these factors. Therefore, the goals are achieved as expected.

\section{REFERENCE}

Aditama TY (2006). Rokok dan Kesehatan. Jakarta: Penerbit Universitas Indonesia Press.

Ali M, Asrori M (2010). Psikologi Remaja Perkembangan Peserta Didik. Jakarta: PT. Bumi Aksara

Ariani RD (2011). Hubungan Antara Iklan Rokok Dengan Sikap Dan Perilaku Merokok Pada Remaja (Studi Kasus di SMA Negeri 4 Semarang). Artikel Ilmiah. Semarang: Program Pendidikan Sarjana Kedokteran Fakultas Kedokteran Universitas Diponegoro.

Azizah N, Amiruddin R, Ansariadi (2013). Faktor yang Berhubungan Dengan Perilaku Merokok Anak Jalanan di Kota Makassar Tahun 2013. Makasar: Fakultas Kesehatan Masyarakat Universitas Hasanuddin Makassar

Depkes RI (2010). Masalah Merokok di Indonesia. Jakarta : Depkes RI.

Geckova AM, Stewart R, Dijk JPV, Orosova O, Groothoff JW, Post D (2005). Influence of socio-economic status, parents and peers on smoking behaviour of adolescents. European Addicted Research. 1 (1): 204-209. https://doi.org/10.1159/000086403

Green LW, Marchel WK (1980). Health promoting planning an educational and environmental aproach. Second Edition. Mountain View: Mayfield Publishing Company

Hasanah AU, Sulastri (2011). Hubungan antara dukungan orang tua, teman sebaya dan iklan rokok dengan perilaku merokok pada siswa laki-laki Madrasah Aliyah Negeri 2 Boyolali. Gaster. 8 (1): 695-705.
Hidayangsih PS, Tjandrarini DH, Mubasyiroh R, Supanni (2011). Buletin Penelitian Kesehatan. 39 (2) 88-98.

Komasari D, Helmi AF (2000). Faktorfaktor penyebab perilaku merokok pada remaja. Jurnal Psikologi, 1(1): 37-47.

Lindawati, Miradwiyana B, Sumiati (2012). Faktor-Faktor Yang Mempengaruhi Perilaku Merokok Siswa-Siswi SMP di Daerah Jakarta Selatan Tahun 2011. Jurnal Health Quality, 2(4): 189-200

Maseda DR, Suba B, Wongkar D (2013). Hubungan pengetahuan dan sikap tentang bahaya merokok dengan perilaku merokok pada remaja putra di SMA Negeri I Tompasobaru. Ejournal Keperawatan (e-Kp). 1 (1):1-8.

Mc Donald P (2004). Understanding smoking behavuir in children and adollescent. Paediatric Nursing. 16(3): 2627.

Mubarak WI (2009). Sosiologi untuk keperawatan: Pengantar dan teori. Jakarta: Salemba Medika.

Mulyana A (2014). Kerangka HAM Bagi Kebijakan Pengendalian Tembakau. Jurnal Wacana Kinerja. 17 (2): 1-23.

Naing NN, Ahmad Z, Musa R, Hamid FRA, Ghazali H, Bakar MHA (2004). Factors related to smoking habits of male adolescents. Tobacco Induced Diseases. 2(3): 133-140. https://dx.doi.org/10.1186\%2F1617-9625-2-3-133

Oktavia D (2011). Faktor-faktor yang berhubungan dengan tindakan merokok siswa laki-laki di SMA Negeri Kota Padang Tahun 2011. Skripsi. Program Studi Ilmu Kesehatan Masyarakat Peminatan Epidemiologi Fakultas Kedokteran Universitas Andalas.

Permatasari I, Wahyuni (2011). Hubungan Pola Asuh Keluarga dan Lingkungan Teman Sebaya dengan Perilaku Merokok Pada Remaja Usia 11-20 Tahun di 
Soesyasmoro et al./ Effect of Knowledge, Peer Group, Family, Cigarette Price, Stipend

Desa Nambuhan Kecamatan Purwodadi Kota Purwodadi Kabupaten Grobogan. Gaster. 8 (1): 706-721.
Theodorus (1994). Ciri perokok di kalangan mahasiswa Universitas Sriwijaya. Jurnal JEN. 1(3): 19-24. 